\title{
Factors Influencing Passengers' Satisfaction with the Light Rail Transit Service in Alpha Cities: Evidence from Kuala Lumpur, Malaysia Using Structural Equation Modelling
}

\author{
Ahmad Nazrul Hakimi Ibrahim 1(D), Muhamad Nazri Borhan 1,2*(D), Muhamad Razuhanafi Mat Yazid 1,2 $\mathbb{D}$, \\ Riza Atiq Rahmat ${ }^{1}$ and Sotaro Yukawa ${ }^{3}$ \\ 1 Department of Civil Engineering, Faculty of Engineering and Built Environment, Universiti Kebangsaan \\ Malaysia, Bangi 43600, Malaysia; nazrulhakimi@siswa.ukm.edu.my (A.N.H.I.); \\ razuhanafi@ukm.edu.my (M.R.M.Y.); rizaatiq@ukm.edu.my (R.A.R.) \\ 2 Sustainable Urban Transport Research Centre (SUTRA), Faculty of Engineering and Built Environment, \\ Universiti Kebangsaan Malaysia, Bangi 43600, Malaysia \\ 3 Department of Economics, Osaka University of Commerce, Mikuriyasakae-machi, Higashiosaka-shi, \\ Osaka 577-8505, Japan; s77yukawa@nifty.com \\ * Correspondence: mnazri_borhan@ukm.edu.my
}

\section{check for} updates

Citation: Ibrahim, A.N.H.; Borhan, M.N.; Mat Yazid, M.R.; Rahmat, R.A.; Yukawa, S. Factors Influencing Passengers' Satisfaction with the Light Rail Transit Service in Alpha Cities: Evidence from Kuala Lumpur, Malaysia Using Structural Equation Modelling. Mathematics 2021, 9, 1954. https://doi.org/10.3390/math9161954

Academic Editors: Gregorio Esteban Giménez and Javier Valbuena

Received: 27 July 2021

Accepted: 12 August 2021

Published: 16 August 2021

Publisher's Note: MDPI stays neutral with regard to jurisdictional claims in published maps and institutional affiliations.

Copyright: (c) 2021 by the authors. Licensee MDPI, Basel, Switzerland. This article is an open access article distributed under the terms and conditions of the Creative Commons Attribution (CC BY) license (https:/ / creativecommons.org/licenses/by/ $4.0 /)$.

\begin{abstract}
Policy makers and service providers must have a good understanding of the determinants of passengers' satisfaction with light rail transit (LRT) in order to be able to formulate effective strategies that ensure passenger satisfaction, which would in turn help to retain existing passengers and attract new ones. This is seen as the most important determinant of the long-term financial performance of LRT service. In this context, the present study seeks to establish the influence of passenger expectation, perceived quality and perceived value on their satisfaction with the service provided. A total of 417 responses from a self-administrated questionnaire were collected from LRT passengers in Kuala Lumpur, Malaysia. The proposed model was tested using a structural equation model. The results proved the significant and direct effect of perceived quality and perceived value on passenger satisfaction. Of the factors, perceived quality is the most critical construct determining the satisfaction level of LRT passengers. The present study concludes by deriving the theoretical and managerial implications on the field of transport. This study provides beneficial information which helps service providers, authorities, policy makers, planners, and researchers formulate effective strategies to increase the use of LRT service, especially in Kuala Lumpur, Malaysia, and other alpha and metropolitan cities in general.
\end{abstract}

Keywords: light rail transit; public transport; railway; service quality; satisfaction; structural equation model

\section{Introduction}

The rapid population growth and urban development in many cities worldwide has led to the massive urbanisation and intricate transformation of the urban landscape. This is one of the phenomena faced by the increasingly higher number of rural people migrating to urban areas in the pursuit of better employment and education opportunities; this has contributed to a higher degree of urban agglomeration. For instance, approximately $80 \%$ of the urban population in European countries is the result of the urbanisation phenomenon [1] The major impact of this phenomenon is a higher demand for transportation. In this regard, the provision of a proper public transport network is of critical importance to reduce dependence on motorised transport. Kwan et al. [2] emphasised that an inadequate public transport network leads to the dependence of motorised transport for mobility. This has contributed to a number of social economic burdens, including massive traffic congestion, risks of road accidents, longer travel time, higher cost, and environmental problems such as air pollution and high carbon dioxide emissions [2-4]. In addition, the use of motorised 
transport could have an adverse impact on human health due to air and noise pollution and the involuntary adoption of a sedentary lifestyle $[5,6]$.

As one of the most developed countries in Southeast Asia, Malaysia experiences significant urbanisation and urban agglomeration. The rate of urbanisation in Malaysia is projected to be about 70\% in the year 2020 [7]. Kuala Lumpur is one of the cities in Malaysia experiencing a rapidly expanding metropolitan area and massive urban development. Ranked as an alpha (an alpha level city is a city that serves the main node in the global economic network) world city, Kuala Lumpur is the financial, cultural and economic centre of the country and is one of three Malaysian Federal Territories [8]. Kuala Lumpur has a very high population density of 6891 people $/ \mathrm{km}^{2}$. The population of Kuala Lumpur in 2016 is 1.76 million, and by the year 2020 Kuala Lumpur is expected to have a population of 2.2 million [8,9]. In its role as an alpha and capital city, Kuala Lumpur is the centre for several activities such as high technology development, education-training, commercial and financial, international business and trade, and others, all of which influence the number of trips made within the city area. Trips in the Kuala Lumpur area are made using private motorised transport such as cars and motorcycles. Chuen et al. [10] and Kwan et al. [2] found that only 17\% (1.24 million) of the trip in Kuala Lumpur are made by public transport, and $83 \%$ (6 million) of the trips are made by private motorised transport. In addition, Mohamad and Kiggudu [11] reported that $70 \%$ of the vehicles plying the major roads during the morning rush hour are single-occupancy vehicles. These evidences proved that the commuting methods used by the residents of Kuala Lumpur are extremely inefficient. This has contributed to the negative effects of the dependence on private motor vehicles discussed in previous works [10-13].

A large amount of transport literature has contended that public transport is a vital element in the global effort to promote sustainable transport $[2,13,14]$. This endeavour could reduce the dependency on private transport and promote the use of sustainable transport; in Kuala Lumpur, for instance, the rail transit service provides an efficient, reliable, affordable and eco-friendly travel alternative. However, according to Masirin et al. [15], the ridership for the rail transit in Kuala Lumpur is still low, even though the government has been making a large investment to encourage the use of rail transit and increase the ridership of rail transit in the past few decades. Similarly, Zulkifli et al. [16] and Ibrahim et al. [17] reported that one of the most serious concerns in Asian transport literature is the low ridership of rail transit. The low ridership of rail transit in Kuala Lumpur is similar with the low rate of public transport usage reported in many other parts on the globe $[13,18]$. Generally, the poor public transport usage is due to the convenience of using private transport, including better flexibility, comfort, privacy and speed, compared to the utilisation of public transport [1,19].

According to Kwan et al. [2], one reason for the low intention to use the railway for commuting in Kuala Lumpur is because the rail transit network only connects $10-20 \%$ of the urban area. In addition, several studies have reported that the reason for the lack of enthusiasm to use rail transit is the failure to provide the level of quality service expected by the passengers $[13,20,21]$. This has caused dissatisfaction with the service provided. According to Shen et al. [22], passengers who are not satisfied with the public transport service would not be loyal to the service and would not recommend it to others. Numerous studies have investigated passengers' satisfaction with rail transit [22-24] and reported that passengers' satisfaction with the service provided is a primary factor influencing their decision to use and promote the railway service to others in the future. Thus, the provision of a high-quality service that meets passengers' expectations would result in passenger satisfaction, which in turn ensures passenger retention and attracts potential passengers to use the service.

As has been pointed out in the various marketing and transport literature, an indicator of a successful public transport service which ensures the ability to survive in the transport market and the ability to compete with other forms of travel mode is the number of passengers that the system is able to retain and attract [22,25]. Thus, there is a critical 
need for the authorities and rail transit service providers to determine whether the services provided adequately satisfy passengers' needs and satisfaction. In addition, the factors which influence passengers' satisfaction with rail transit have to be established to enable researchers, policy makers, engineers, service providers and the authorities to formulate strategic measures which would enhance passengers' satisfaction with rail transit and thus increase ridership. Therefore, this paper attempts to investigate the factors influencing the satisfaction of rail transit passengers based on the evidence from the light rail transit (LRT) in Kuala Lumpur. The covariance-based structural equation model (CB-SEM) approach is used to assess the relationship between the constructs, namely passenger expectation, perceived quality, perceived value and passengers' satisfaction with the LRT service. There are several advantages offered by this approach. In a statistic point of view, SEM is an advanced linear model approach which involves the multiple regression analysis to investigate the consistency of the hypothesised model with the data collected [26]. Additionally, Williams et al. [27] stated that SEM is a multivariate analytical method employed to assess and evaluate the complex causal relationship between constructs, even when the relationship is hypothetical direct or not directly observable. In general, the SEM approach is popular and is preferred in social science and management studies because it can assess the measurement model and structural path efficiently, especially when the structural model consists of multiple dependent variables, latent constructs based on multi-item indicator variables, and multiple stages/levels of constructs in a structural model [28]. Due to its robustness, the SEM approach has gained attention in the transportation sector. The present study hopes to provide useful information that would help service providers, authorities, policy makers, planners and researchers formulate effective strategies to increase the use of rail transit, especially in Kuala Lumpur, and in other alpha and metropolitan cities in general.

The rest of the paper is organised as follows. Section 2 discusses the reviewed literature and hypothesis development. Section 3 describes the adopted methodology. Section 4 presents and analyses the results of the study, and Section 5 explains their implications. Section 6 draws the conclusion from the present study.

\section{Hypothesis Development and Conceptual Framework}

\subsection{Passenger Expectation}

Passenger expectation is derived from the passengers' earlier experience with other products or service providers, and this experience shapes the passengers' expectation of the ability of any company to provide a product or service in the future $[29,30]$. According to Fornell [29], passenger expectation is positively and directly related with perceived performance, quality of service, perceived value and customer satisfaction. This contention is supported by Oliver [31,32] based on the expectancy-disconfirmation model framework, which considers expectations as one of the most important antecedents of perceived quality, perceived value and user satisfaction.

Numerous previous works in the field of transportation have reported passenger expectation as an important factor influencing passenger satisfaction. Shen et al. [22] investigated urban rail and found that passenger expectation can influence perceived quality, perceived value and passenger satisfaction. Another study of the Chinese public transport service by Zhang et al. [33] showed a similar trend of the relationship, and their findings are supported by those made by Shen et al. [22]. Hussain et al. [34] reported that passenger expectation has a considerable positive influence on perceived quality, although the researchers were not able to demonstrate any significant effect on perceived value based on their investigation of the airline service in the United Arab Emirates (UAE). This outcome is congruent with the findings of an investigation on the public transport in Suzhou, China [35]. Based on a review of the literature, it is evident that passenger expectation may influence perceived quality, perceived value and passenger satisfaction. Thus, on the basis of this evidence, the following hypotheses are proposed: 
Hypothesis 1 (H1). Passengers' expectation towards LRT service has a positive effect on perceived quality.

Hypothesis 2 (H2). Passengers' expectation towards LRT service has a positive effect on perceived value.

Hypothesis 3 (H3). Passengers' expectation towards LRT service has a positive effect on the satisfaction of LRT passengers.

\subsection{Perceived Quality}

To date, exploration of the theories and practices of service quality has been attracting increasing attention from practitioners and researchers from many different fields. Service quality is defined as the overall customer assessment of the service provider's performance [36]. Additionally, Lai and Chen [23] proposed that service quality is a degree to which the provided service fulfils the consumer's needs. In much of the reviewed literature, service quality is considered an important predictor of customer satisfaction [37-40]. A high service quality leads to higher perceived quality by the customer. Perceived quality, or perceived service quality, is consumer perception of the services offered by an entity that includes the full accomplishment of superiority [41], and several studies reported that it is a key factor influencing customer (or passenger) satisfaction, including in the field of transportation.

In a study investigating rail-based public transport, Mouwen [40] found that travel speed and punctuality are among the service quality which have the strongest influence on user satisfaction. Lai and Chen [23] found that the quality of service provided by the Kaohsiung Mass Rapid Transit (KMRT) is a statistically significant factor influencing the passengers' perceived value, satisfaction and involvement. In addition, Shen et al. [22] reported that perceived quality has a significant positive and direct effect on the perceived value and passenger satisfaction with the Suzhou rail transit service. Two studies on the service quality of metro [42] and high-speed rail [24] in Turkey discovered that the service quality provided by both service providers is in proportion with user satisfaction. Other studies on public transportation [43-48] have reported outcomes consistent with the studies discussed above. In summary, perceived quality may influence perceived value and user satisfaction. Thus, the following hypotheses are developed based on a comprehensive review of the literature:

Hypothesis 4 (H4). Perceived quality has a positive effect on perceived value.

Hypothesis 5 (H5). Perceived quality has a positive effect on the satisfaction of LRT passengers.

\subsection{Perceived Value}

Perceived value originates from the equity theory concerned with the input or outcome ratio of the customer and service provider [49]. According to Bolton and Drew [50], the underlying concept of equity theory is the things customers deem as right, fair or should be the perceived value of the offering. Specifically, it is the judgment made by customers (or passengers) based on how they perceive a product (or service) offered by the supplier (or service provider) [51]. Lai and Chen [23] believed that perceived value is dependent on the customer's perceived cost and perceived benefits. Yang and Peterson [52] divided perceived value into monetary and non-monetary investments. In monetary investment, consumers pay for the offered product (or service quality) using banknote. However, non-monetary investment is related to factors such as stress experience, time and energy consumption.

Several transportation studies reported that perceived value has a positive effect on passenger satisfaction. A survey carried out by Shen et al. [22] in China showed a positive and direct correlation between the perceived value of the Suzhou rail transit system and passenger satisfaction. Irtema [53] used the structural equation model (SEM) to analyse the feedback from 412 public transportation users in Kuala Lumpur and found that the 
passengers' satisfaction and perceived value of the public transportation are statistically significant. A case study of the KMRT in Taiwan revealed a significant correlation between perceived value and passenger satisfaction [23]. Similarly, in Jakarta, Indonesia, Sumaedi et al. [54] reported that the perceived value of the paratransit passengers has a direct and positive effect on their satisfaction. This finding is consistent with the those obtained by empirical studies on public transportation [55-58]. In summary, perceived value has a significant effect on passenger satisfaction. Thus, if users showed a high approval of the advantages and benefits of public transportation, they are more likely to be more satisfied with the service provided and thus are more inclined to use the service in the future and recommend the service to others. The comprehensive literature review has led to the formulation of the following hypothesis:

Hypothesis 6 (H6). Perceived value has a positive effect on the satisfaction of LRT passengers.

\subsection{Conceptual Framework}

Based on the comprehensive literature review and the hypotheses proposed in this study, the conceptual framework that links passenger expectation (PE), perceived quality $(\mathrm{PQ})$, perceived value (PV), and satisfaction (PS) is illustrated in Figure 1. Therefore, the effect and interrelationships of these factors (PE, $\mathrm{PQ}$ and $\mathrm{PV}$ ) on passengers' satisfaction with light rail transit service in Kuala Lumpur, Malaysia are comprehensively investigated.

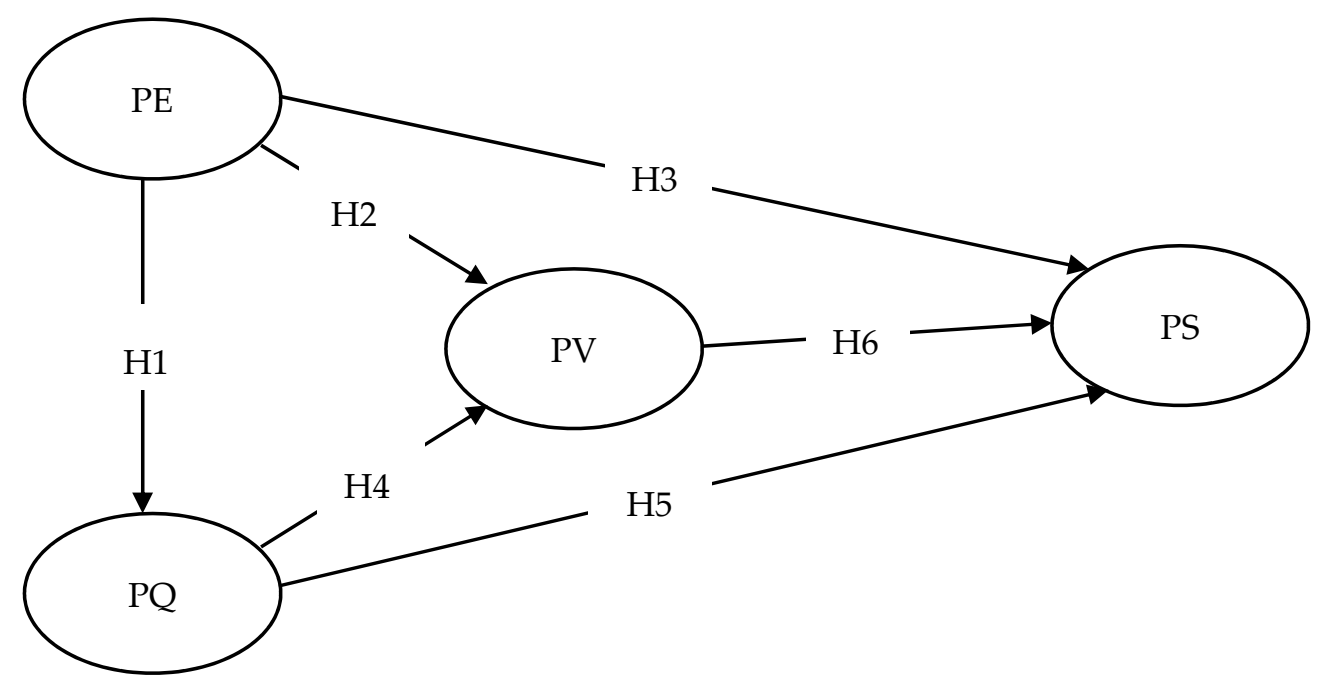

Figure 1. Conceptual framework of the research model.

\section{Methodology}

This paper considers the light rail transit (LRT) system in Kuala Lumpur as a case study. Figure 2 shows the LRT system, which comprises three lines; the Ampang Line spans $18 \mathrm{~km}$ and has 18 stations, the Sri Petaling Line spans $45.1 \mathrm{~km}$ long and has 29 stations, and the Kelana Jaya Line spans $46.4 \mathrm{~km}$ and has 37 stations [59]. Table 1 shows the instrument employed in this study. The study instrument is adopted and modified from earlier studies and has been back-translated into Malay. Prior to the final data collection, the questionnaire was administered on 50 randomly selected respondents in Bandar Baru Bangi, Selangor as a pilot test. The pilot test evaluates any weakness in the designed instrument and helps the researchers improve the questionnaire before administrating the actual survey [3]. Based on the feedback from the respondents of the pilot test, several questions were omitted from the questionnaire because the participants did not answer them or the answers were erroneous. Other questions were modified to improve clarity and reliability. Table 1 shows the results of the reliability analysis of the pilot study. The questionnaire used in the final data collection in this study consists of two main sections: (i) Section 1: Respondents demographic characteristics, and (ii) Section 2: LRT passengers' satisfaction evaluation, 
as presented in Appendix A. The five-point Likert scale for measuring the questions in Section 2 ranges from $1=$ Strongly disagree to $5=$ Strongly agree. A high score indicates a higher interest in a measure.

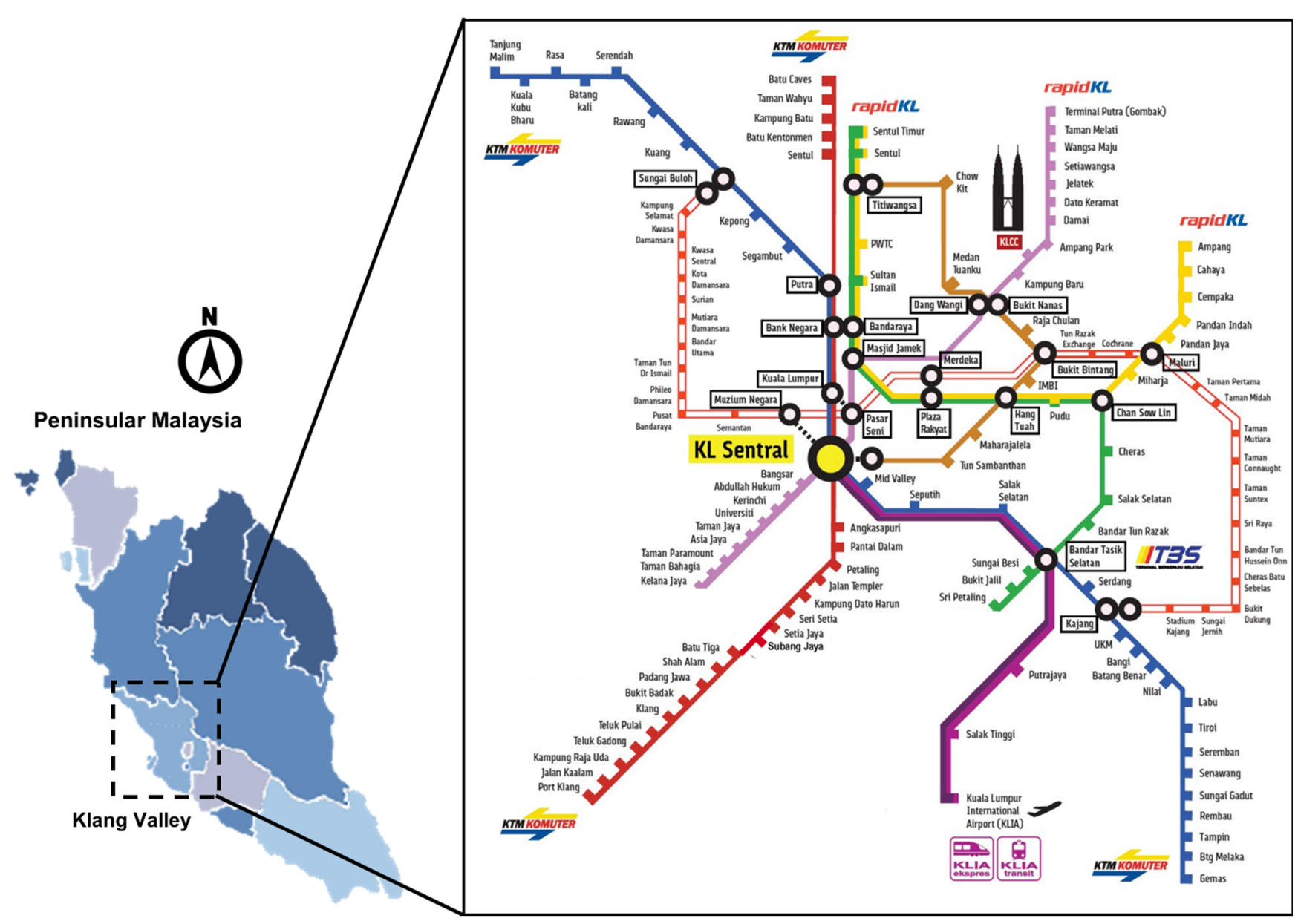

Figure 2. The Ampang line (yellow), Sri Petaling line (light green), and Kelana Jaya line (pink) of the rail transit network in Kuala Lumpur.

Table 1. Construct items and reliability analysis of the instruments.

\begin{tabular}{cccc}
\hline Construct & Adopted From: & Number of Items & Cronbach Alpha $(\boldsymbol{\alpha})$ \\
\hline Passenger Expectation & {$[22]$} & 3 & 0.871 \\
Perceived Quality & {$[22,53]$} & 8 & 0.883 \\
Perceived Value & {$[22,53]$} & 5 & 0.905 \\
Passenger Satisfaction & {$[22,53]$} & 4 & 0.870 \\
\hline
\end{tabular}

In this study, the cross-sectional questionnaire survey was administered at two major stations which have the highest number of passengers, namely Kuala Lumpur Central and Terminal Bersepadu Selatan (TBS), on the basis of convenience sampling. Prior to administering the survey, the enumerators were given a simple briefing regarding the purpose of the survey and the potential respondents were asked about their willingness to participate in the survey. The questionnaire was distributed only to those willing to participate in the survey to ensure they gave an accurate and reliable response to all items in the questionnaire. This approach would increase the response rate of the survey [60]. The interview was face-to-face, and the respondents were given a small token of appreciation at the end of the 10-15 min survey. Five hundred self-administrated questionnaires were administered between 20 September 2019 and 10 December 2019. Eighty-three question- 
naires were eliminated because of invalid or/and incomplete responses, and 417 of the questionnaires were considered for further analysis, giving an effective response rate of $83.40 \%$. The data were analysed using IBM SPSS Statistics version 24.0 and IBM SPSS Analysis of Moment Structure (Amos) version 24.0. This study includes respondents' demographic characteristics and the measurement and structural model as a part of the systematic procedure for data analysis.

\section{Results}

\subsection{Respondents' Demographic Characteristics}

The demographic characteristics of the 417 respondents are presented in Table 2. Of the total respondents, $50.8 \%$ are male and $49.2 \%$ are female. Most of the respondents, almost $44 \%$, are from the $21-30$-year-old age group, $37.4 \%$ are in the $31-40$-year-old age group, $9.1 \%$ are less than 20 years old, $8.6 \%$ are in the $41-50$-year-old age group, and $1.2 \%$ are over 50 years old. More than half of the respondents $(74.6 \%)$ have a university degree. Over half of the respondents (55.9\%) are full-time employee, $32.4 \%$ are students, $5.8 \%$ are unemployed, $5.5 \%$ hold a part-time job, and $0.5 \%$ are in other categories. Concerning their income, $29.3 \%$ of the respondents earn less than MYR 2000 per month, only $1.0 \%$ earns more than MYR 8000 per month, and $18.7 \%$ chose not to state their monthly income. The questionnaire also asked if the respondents hold a driving licence and if their household own any car. The majority of the respondents (85.4\%) hold a driving license and $14.6 \%$ do not hold a driving license. Furthermore, $27.8 \%$ of the respondents do not own a car, and of the remaining $72.2 \%$ respondents, $33.6 \%$ owned one car, $23.3 \%$ owned two cars, and $15.3 \%$ owned three or more cars.

Table 2. Profile of respondents $(n=417)$.

\begin{tabular}{|c|c|c|c|c|c|}
\hline & $\mathbf{n}$ & $\%$ & & $\mathbf{n}$ & $\%$ \\
\hline Gender & & & $\begin{array}{l}\text { Income Range } \\
\text { (MYR/Month) }\end{array}$ & & \\
\hline Male & 212 & 50.8 & Less than 2000 & 122 & 29.3 \\
\hline Female & 205 & 49.2 & 2001-4000 & 72 & 17.3 \\
\hline Age (Years) & - & - & $4001-6000$ & 121 & 29.0 \\
\hline Less than 20 & 38 & 9.1 & 6001-8000 & 20 & 4.8 \\
\hline $21-30$ & 182 & 43.6 & More than 8000 & 4 & 1.0 \\
\hline $31-40$ & 156 & 37.4 & Private & 78 & 18.7 \\
\hline $41-50$ & 36 & 8.6 & Driving License Ownership & - & - \\
\hline 50 and above & 5 & 1.2 & Yes & 356 & 85.4 \\
\hline Education & - & - & No & 61 & 14.6 \\
\hline Primary School & 5 & 1.2 & Car Ownership & - & - \\
\hline Secondary School & 30 & 7.2 & 0 & 116 & 27.8 \\
\hline College & 68 & 16.3 & 1 & 140 & 33.6 \\
\hline University Degree & 311 & 74.6 & 2 & 97 & 23.3 \\
\hline Other & 3 & 0.7 & More than 3 & 64 & 15.3 \\
\hline Occupation & - & - & - & - & - \\
\hline Full-Time Employee & 233 & 55.9 & Note: MYR 1 ₹ USD 0.23 & & - \\
\hline Part-Timer Employee & 23 & 5.5 & - & - & - \\
\hline Unemployed & 24 & 5.8 & - & - & - \\
\hline Student & 135 & 32.4 & - & - & - \\
\hline Other & 2 & 0.5 & - & - & - \\
\hline
\end{tabular}

\subsection{Evaluation of the Measurement Model}

Table 3 presents the fit indices of the measurement model for this study. All values of the fit indices-namely the ratio of chi-square to degrees of freedom $(\chi 2 / \mathrm{df})$, comparative fit index (CFI), normed fit index (NFI), goodness-of-fit index (GFI), adjusted goodness of fit index (AGFI), and root mean square error of approximation (RMSEA) - comply with the cut off criterion recommended by the previous works in the field of transport. The results of the fit indices for the measurement model indicate that the model fits the empirical 
data well. The measurement model was then validated by three approaches; consistency reliability, convergent validity and discriminant validity.

Table 3. Summary of the measurement model fit indices.

\begin{tabular}{ccccc}
\hline Fit Indices & Result & Cut off Criterion & Status & Reference \\
\hline X2/df & 2.54 & $<3.00$ & Acceptable & \\
CFI & 0.96 & $>0.90$ & Acceptable & \\
NFI & 0.94 & $>0.90$ & Acceptable & {$[3,12,24,35]$} \\
GFI & 0.95 & $>0.90$ & Acceptable & \\
AGFI & 0.94 & $>0.90$ & Acceptable & \\
RMSEA & 0.07 & $<0.10$ & Acceptable & \\
\hline
\end{tabular}

Note: $\chi 2 / d f$, Ratio of chi-square to degrees of freedom; CFI, Comparative fit index; NFI, Normed fit index; GFI Goodness-of-fit index; AGFI, Adjusted goodness of fit index; RMSEA, Root mean square error of approximation.

\subsubsection{Construct Reliability}

Ibrahim et al. [3] stated that construct reliability measures the internal consistency of the data measuring tool's coefficient for each construct. The Cronbach's alpha and composite reliability were calculated to establish the reliability of the construct. According to Hair et al. [61], a Cronbach's alpha and composite reliability greater than 0.70 is considered to be satisfactory. As can be seen in Table 4, the Cronbach alpha and composite reliability values range between $0.863-0.916$ and $0.900-0.947$, respectively, which indicate that the constructs are reliable.

Table 4. Results of construct reliability, convergent validity, and discriminant validity.

\begin{tabular}{|c|c|c|c|c|c|c|c|c|}
\hline \multirow{2}{*}{ Construct } & \multirow{2}{*}{ Item Loading (Range) } & \multirow{2}{*}{ Cronbach Alpha $(\alpha)$} & \multirow{2}{*}{ Composite Reliability } & \multirow{2}{*}{ AVE } & \multicolumn{4}{|c|}{ Factor Correlation } \\
\hline & & & & & PE & $P Q$ & PV & PS \\
\hline PE & $0.874-0.963$ & 0.916 & 0.947 & 0.857 & 0.93 & - & - & - \\
\hline PQ & $0.693-0.880$ & 0.866 & 0.928 & 0.517 & 0.71 & 0.72 & - & - \\
\hline $\overrightarrow{P V}$ & $0.654-0.914$ & 0.887 & 0.900 & 0.647 & 0.68 & 0.58 & 0.80 & - \\
\hline PS & $0.781-0.883$ & 0.863 & 0.907 & 0.709 & 0.70 & 0.64 & 0.61 & 0.84 \\
\hline
\end{tabular}

Note: $p<0.05$; AVE, Average variance extracted; PE, Passenger expectation; PQ, Perceived quality; PV, Perceived value; PS, Passenger satisfaction.

\subsubsection{Convergent Validity}

According to Hair et al. [61], the definition of convergent validity is the degree to which a measure is positively correlated with the alternative measures of the same construct. The validity was assessed on the basis of two criteria: (i) the standardised factor loading (or item loading) should be greater than 0.50 and significant [61], and (ii) the average variance extracted (AVE) for all constructs must be at least 0.50 [62]. As can be seen in Table 4, the standardised factor loading for all items are greater than the threshold value of 0.50 , where the minimum item loading is 0.654 and is thus significant. In addition, the values of all AVE range between 0.517 and 0.857 , which are greater than the 0.50 threshold value recommended by Fornell and Larcker [62]. Therefore, the convergent validity has been proven to be good as all constructs fulfilled the above-mentioned criteria.

\subsubsection{Discriminant Validity}

The definition of discriminant validity given by Hair et al. [61] is the degree to which a construct is truly distinct from others based on empirical standards. This validity is measured by comparing the AVE value of each construct with the squared correlation between these constructs as well as with all other constructs [35]. The results presented in Table 4 shows that the AVE values for all constructs are higher than the squared correlation and meet the requirement proposed by Fornell and Larcker [62]. Thus, the discriminant validity in this study is acceptable. 


\subsection{Evaluation of the Structural Model}

After confirming the validity and reliability of the measurement model, the recommended hypotheses were evaluated using covariance-based structural equation model (CB-SEM). Results showed that the model for exploring the determinants of passengers' satisfaction with the Kuala Lumpur LRT service is well-fitted as all values of the goodnessof-fit indices $\left(\chi^{2} / \mathrm{df}=2.63, \mathrm{CFI}=0.95, \mathrm{NFI}=0.93, \mathrm{GFI}=0.95, \mathrm{AGFI}=0.93, \mathrm{RMSEA}=0.07\right)$ satisfy the requirement for fit criteria. The overall model structure with the standardised estimates and the significance of the relationship between the constructs is illustrated in Figure 3. The structural equation model (see Figure 3) explained $28 \%$ of the variance in perceived quality, $61 \%$ of the variance in perceived value, and $76 \%$ of the variance in passenger satisfaction.

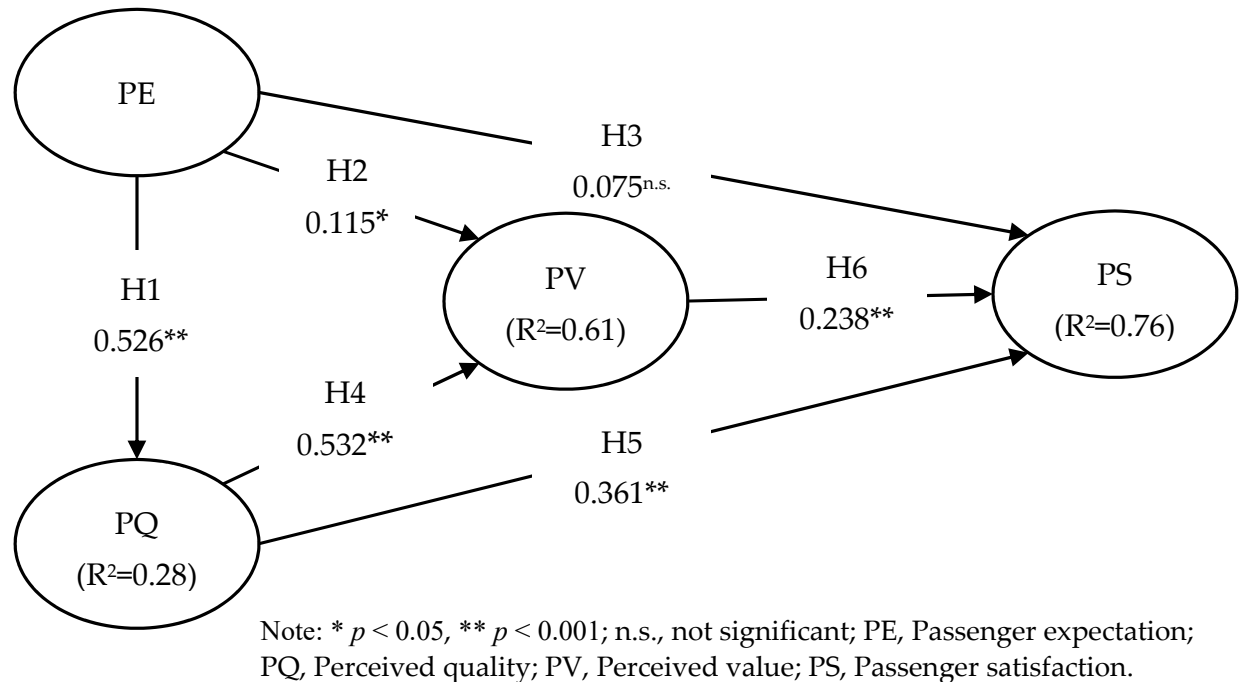

Figure 3. Structural equation model.

Hypotheses 1 to 3 suggest that passenger expectation has a positive impact on perceived quality, perceived value and passenger satisfaction. The standardised regression coefficient presented in Figure 3 shows that passenger expectation has a significant positive and direct effect on perceived quality $(\beta=0.526, p<0.001)$ and perceived value $(\beta=0.115$, $p<0.05)$ and not significant effect on passenger satisfaction $(\beta=0.075, p>0.05)$. Thus, hypotheses 1 and 2 are supported, while hypothesis 3 is not supported. The positive relationship between perceived quality and perceived value and between perceived quality and passenger satisfaction is stated in hypotheses 4 and 5 . The results indicate that perceived quality has a significant positive influence on perceived value $(\beta=0.532, p<0.001)$ and passenger satisfaction $(\beta=0.361, p<0.001)$. These results confirm hypotheses 4 and 5. Hypothesis 6 states that perceived value has a positive impact on passenger satisfaction, and the result showed a significant positive relationship between the two constructs ( $\beta=0.238, p<0.001$ ). Therefore, hypothesis 6 is accepted. A summary of the hypothesis testing model is given in Table 5 .

Table 5. Summary of hypothesis testing model.

\begin{tabular}{|c|c|c|c|c|c|}
\hline Hypothesis & \multicolumn{3}{|c|}{ Relationship } & $\beta$ & Hypothesis \\
\hline H1 & Passenger expectation & with & Perceived quality & $0.526^{* *}$ & Supported \\
\hline $\mathrm{H} 2$ & Passenger expectation & with & Perceived value & $0.115 *$ & Supported \\
\hline H3 & Passenger expectation & with & Passenger satisfaction & $0.075^{\text {n.s. }}$ & Not supported \\
\hline $\mathrm{H} 4$ & Perceived quality & with & Perceived value & $0.532 * *$ & Supported \\
\hline H5 & Perceived quality & with & Passenger satisfaction & $0.361^{* *}$ & Supported \\
\hline H6 & Perceived value & with & Passenger satisfaction & $0.238 * *$ & Supported \\
\hline
\end{tabular}

Note: H, Hypothesis; $\beta$, Standardised regression coefficient; ${ }^{*} p<0.05,{ }^{* *} p<0.001 ;$ n.s., not significant. 


\section{Discussion of the Results}

\subsection{Theoretical Implications}

This study aims to explore the determinants of passenger satisfaction in the context of light rail transit (LRT) service in Kuala Lumpur, Malaysia, which is an alpha city in the South Asian region, by investigating the role of passenger expectation, perceived quality and perceived value based on the passengers' past experience with the Kuala Lumpur's LRT service. The interrelationship of the model was tested using a set of data obtained through a customer satisfaction survey of the urban rail transit in Kuala Lumpur, Malaysia using a structural equation model approach. The conceptual framework in this study was assessed and validated, and this theoretically contributed to the understanding of the factors influencing passengers' satisfaction with the urban rail transit. It is crucial to explore the factors influencing passengers' satisfaction with the urban rail transit, especially in the context of Malaysia, given that rail transit is one of the government's strategies to reduce the dependency on private motorised transport and to increase the public transport modal share up to $40 \%$ in 2030 [63]. Specifically, the rail transit in the urban area of the future will be the backbone of the public transport network in the city.

According to this study, three factors-namely passenger expectation, perceived quality and perceived value-can have a direct or indirect impact on passenger satisfaction. The outcomes of this study are congruent with the earlier research in transportation. The present study found that passenger expectation has a direct and significant effect on perceived quality, perceived value and passengers' satisfaction level towards the LRT service. Put differently, passenger expectation not only has a direct influence on their level of satisfaction, but it also has an indirect influence on passenger satisfaction via perceived quality and perceived value. This finding is congruent with those made by Shen et al. [22] and Zhang et al. [33]. The findings also confirmed the positive influence of perceived quality on perceived value and passenger satisfaction reported in various previous research [23,43-48]. Similar with the evidences provided by previous studies, the structural equation model used in this study justifies the significant and positive influence of perceived value on satisfaction with the LRT service [53-58]. Hence, passenger expectation, perceived quality and perceived value can be considered as antecedents to passengers' satisfaction with the LRT service in Kuala Lumpur.

Of the three factors influencing the satisfaction level of the passengers of Kuala Lumpur LRT service, perceived quality was found to be the strongest determinant of the feeling of satisfaction among passengers. This finding is consistent with those of recent works in the field of public transport $[22,23,38,53]$. It is apparent that passengers who use urban rail transit service, in this context the LRT, have a higher level of satisfaction when the service provided is beyond their expectation. In other words, the high-quality service brings about a higher level of satisfaction with the LRT service. According to Ibrahim et al. [13], punctuality, number of trips per day, ticket price or types of passes, cleanliness and comfort in both in the train and at the station, safety on the train and at the station, customer service and more are the main elements of service quality that have been proven to affect perceived service quality as well as passengers' satisfaction with rail-based public transport. This study also found that passengers would be more satisfied with the LRT service if they felt that the trip with the LRT was good value. In this study, value is made up of perceived cost (monetary) and perceived benefits (non-monetary) [52]. The low cost of the trip, short travel time, and comfort during the journey are the indicators that contribute to the perceived value in public transport generally and in urban rail transit specifically. Given that these factors have a direct effect on passenger satisfaction, they have to be given serious consideration in the effort to enhance passengers' satisfaction with the LRT service.

The effort to understand the factors influencing user satisfaction in the attempt to formulate better strategies to enhance the passengers' satisfaction level and to increase ridership of the rail transit service in the Southeast Asia region, especially in Malaysia, is still limited in the literature in the transportation domain. Das et al. [45] assessed passengers 
satisfaction with light rail transit by focussing on the monorail service in Kuala Lumpur, Malaysia via important performance analysis (IPA). A recent study by Phoong et al. [64] investigated the service quality elements that Kuala Lumpur's LRT passengers satisfied the most via the factor analysis and correlation analysis approach. Therefore, the current study has contributed to enriching the existing body of knowledge and to the literature relating to passengers' satisfaction with the LRT service in the Southeast Asia region, specifically in Malaysia. The consideration of a number of elements, namely passenger expectation, perceived quality and perceived value, in this study has enhanced the predictive ability of a complex sensation such as satisfaction. This is another noteworthy theoretical contribution by this study.

\subsection{Managerial Implications}

From the managerial perspective, the findings of this study have several important implications for the LRT service providers in their effort to enhance passengers' satisfaction with the service provided and in formulating an effective strategy for retaining the current passengers as well as attracting potential passengers. These findings would enable the LRT service to remain competitive in an urban transportation market such as Kuala Lumpur. This is consistent with the implication of previous research which reported that passengers who are satisfied with the service provided are more loyal to the service and promote the service to others $[17,18,65]$.

Based on the above-mentioned outcomes, the most critical factor influencing passengers' satisfaction with the LRT service in Kuala Lumpur is perceived quality. Therefore, LRT service providers should invest more resources and give more focus to physical policies in order to be able to provide a high-quality service which meets passengers' expectations, which in turn brings about passengers' satisfaction after using the service. In view of this, LRT service providers should provide a high quality service, for example by ensuring good facilities on the train and at the station by providing an adequate number of vending machines, seats for waiting, suitable and sufficient handrail or grip straps in the train for standing passengers, a safe environment at the LRT station and on the train, a reasonable fare, a wide network coverage, punctual and high frequency service, sufficient parking space at the stations, and convenience in the train and at station. In addition, passenger satisfaction could be enhanced by providing a fast, punctual and affordable feeder bus service to/from the LRT station and this in turn could contribute to increasing ridership. This is consistent with the contention made by Jain et al. [66] and Chandra et al. [67] that the first mile and last mile transport connectivity facility (feeder bus) have a significant impact in increasing ridership.

A number of policies can be introduced to improve cleanliness and comfort on the train and at the stations, including providing sufficient number of waste bins at specific locations, prohibiting eating and drinking on the train, and introducing a recycling campaign at the stations by providing recycling bins and putting up poster about the recycling campaign. Moreover, the level of safety and security at the station and in the train are vital elements in the formation of passenger satisfaction $[13,59]$. Thus, several steps can be taken to improve the level of safety and security of LRT service; this includes installing closedcircuit televisions (CCTVs) to monitor passenger movement and any suspicious behaviour of the passengers, encouraging the public to report suspicious activities to the security staff, and assigning a sufficient number of security staff on the platform and at the stations. Other measures to enhance passenger satisfaction include providing special assistance for senior citizens and designating coaches only for female passengers.

On the basis of the results of this study, LRT service providers should make an effort to improve passenger satisfaction with the service provided by enhancing perceived value. This is in line with the findings of previous similar studies [53-58] which reported a direct positive relationship of perceived value with passenger satisfaction. A number of measures can be implemented to improve perceived value, including charging a reasonable fare for the service provided in comparison to the fares charged by competitors such as buses, 
taxis and e-hailing service. In view of this, LRT service providers are recommended to introduce several types of ride passes, such as daily, weekly and monthly passes, as well as offering different fare structures and discounts to specific group of passengers such as senior citizens, students, children, and people with disabilities. In addition, non-monetary cost such as effort, energy and time should not be overlooked. The service providers must make sure that the perceived benefits and eco-friendliness of the service provided must be superior to those offered by other types of public transport, informal public transport such as e-healing service (e.g., Grab and MyCar), and private transport. In this context, the provision of high-quality service, such as a punctual, safe, clean, accessible and convenient LRT service may result in enhanced perceived benefits, which partially contribute to the perceived value of the LRT service.

In summary, the provision of service quality and service value that meets passenger expectation will bring about passenger satisfaction with the LRT service in Kuala Lumpur, Malaysia. The measures and policies discussed above are among the methods for enhancing passenger satisfaction with this service, which in consequence help to retain current passengers and attract potential passengers to use this service. The findings of this study provide a rationale for LRT service providers in formulating strategies and making investments to increase ridership in line with the Malaysian government's agenda to make the rail transit as the future spine of transport network in Kuala Lumpur and to increase the public transport modal share in the city area [63].

\section{Conclusions}

This study has demonstrated the impact of passenger expectation, perceived quality and perceived value towards passengers' satisfaction with the light rail transit (LRT) service. Based on the author's knowledge, this is the very first study to assess the relationship of these determinants (passenger expectation, perceived quality and perceived value) in the context of rail transit, particularly LRT, in an alpha city in the Southeast Asia region. In summary, the findings of this study indicate that passenger expectation, perceived quality and perceived value have a considerable influence on enhancing the satisfaction level of LRT passengers. These findings can contribute to the improvement of both theoretical and managerial aspects. In terms of the theoretical aspect, this study has contributed to the enhancement of the fundamental knowledge related to the factors that influence passengers' satisfaction with the LRT service by assessing the complex relationship of the four constructs of the proposed model. Thus, the findings of this study have contributed important information to the transport literature. With regard to the managerial aspect, the results showed that the weight of the constructs influenced passenger satisfaction. This is crucial in helping service providers, authorities, policy makers, planners and researchers formulate effective strategies to increase the use of rail transit, specifically in Kuala Lumpur and in other alpha and metropolitan cities generally.

Author Contributions: Conceptualization, A.N.H.I. and M.N.B.; methodology, A.N.H.I., M.N.B. and M.R.M.Y.; software, A.N.H.I. and M.R.M.Y.; validation, A.N.H.I. and S.Y.; formal analysis, A.N.H.I. and M.R.M.Y.; data curation, A.N.H.I. and M.N.B.; writing—original draft preparation, A.N.H.I. and M.R.M.Y.; writing—review and editing, A.N.H.I., M.N.B. and S.Y.; supervision, M.N.B. and R.A.R.; project administration, M.N.B.; funding acquisition, M.N.B. All authors have read and agreed to the published version of the manuscript.

Funding: This research was sponsored by Universiti Kebangsaan Malaysia (UKM) through Project GUP-2019-015.

Institutional Review Board Statement: Ethical review and approval were waived for this study, due to this study did not involve biological human experiment and patient data.

Informed Consent Statement: Informed consent was obtained from all subjects involved in the study.

Data Availability Statement: All relevant data are within the paper. 
Acknowledgments: The first author would like to acknowledge Yayasan Canselor UKM for the doctoral scholarship under the Skim Zamalah Yayasan Canselor 2019. In addition, the authors would like to thank the anonymous reviewers for their helpful suggestions and comments.

Conflicts of Interest: The authors declare no conflict of interest.

Appendix A

\begin{tabular}{|c|c|c|}
\hline Construct/Item & Abrv. & Standardised Loading \\
\hline Passenger Expectation & PE & - \\
\hline Overall expectation of the LRT service prior to using the service & PE1 & 0.939 \\
\hline $\begin{array}{l}\text { Expectation of the degree to which the LRT service is able to fulfil } \\
\text { passenger requirement prior to using the service }\end{array}$ & PE2 & 0.963 \\
\hline Expectation of the reliability of the service prior to using it & PE3 & 0.874 \\
\hline Perceived Quality & $\mathbf{P Q}$ & - \\
\hline Passenger satisfaction with the signage at the station & PQ1 & 0.713 \\
\hline Passenger satisfaction with the comfort level & PQ2 & 0.695 \\
\hline Passenger satisfaction with the speed of the service & PQ3 & 0.773 \\
\hline Passenger satisfaction with the safety level & PQ4 & 0.745 \\
\hline Passenger satisfaction with the ticketing service & PQ5 & 0.880 \\
\hline Passenger satisfaction with the provided facilities & PQ6 & 0.836 \\
\hline Passenger satisfaction with the customer service & PQ7 & 0.723 \\
\hline Passenger satisfaction with the provision of information & PQ8 & 0.693 \\
\hline Perceived Value & PV & - \\
\hline Evaluation of service based on current ticket price & PV1 & 0.876 \\
\hline Evaluation of ticket price based on the current level of service & PV2 & 0.870 \\
\hline The cost for using the LRT service is cheap & PV3 & 0.654 \\
\hline The time I spent using the LRT service is very reasonable & PV4 & 0.669 \\
\hline $\begin{array}{l}\text { The overall assessment for my experience of using the LRT } \\
\text { service is "excellent value" }\end{array}$ & PV5 & 0.914 \\
\hline Passengers Satisfaction & PS & - \\
\hline Overall satisfaction with the quality of LRT service & PS1 & 0.827 \\
\hline $\begin{array}{l}\text { My perception towards the service provided is beyond my } \\
\text { expectation }\end{array}$ & PS2 & 0.781 \\
\hline $\begin{array}{l}\text { My perception of the comprehensiveness of the services provided } \\
\text { is beyond my expectation }\end{array}$ & PS3 & 0.873 \\
\hline I think I have benefited from using the LRT service & PS4 & 0.883 \\
\hline
\end{tabular}

\section{References}

1. Borhan, M.N.; Ibrahim, A.N.H.; Syamsunur, D.; Rahmat, R.A. Why Public Bus is a Less Attractive Mode of Transport: A Case Study of Putrajaya, Malaysia. Period. Polytech. Transp. Eng. 2017, 47, 82-90. [CrossRef]

2. Kwan, S.C.; Sutan, R.; Hashim, J.H. Trip characteristics as the determinants of intention to shift to rail transport among private motor vehicle users in Kuala Lumpur, Malaysia. Sustain. Cities Soc. 2018, 36, 319-326. [CrossRef]

3. Ibrahim, A.N.H.; Borhan, M.N.; Rahmat, R.A.O. Understanding Users' Intention to Use Park-and-Ride Facilities in Malaysia: The Role of Trust as a Novel Construct in the Theory of Planned Behaviour. Sustainability 2020, 12, 2484. [CrossRef]

4. Borhan, M.N.; Akhir, N.M.; Ismail, A.; Rahmat, R.A.A.O. Pemodelan Hubungan Antara Kualiti Perkhidmatan, Kesan Alam Sekitar, Sikap dan Keinginan untuk Menggunakan Park-and-Ride. J. Kejuruter. 2015, 27, 63-70. [CrossRef]

5. Khreis, H.; Warsow, K.M.; Verlinghieri, E.; Guzman, A.; Pellecuer, L.; Ferreira, A.; Jones, I.; Heinen, E.; Rojas-Rueda, D.; Mueller, $\mathrm{N}$.; et al. The health impacts of traffic-related exposures in urban areas: Understanding real effects, underlying driving forces and co-producing future directions. J. Transp. Health 2016, 3, 249-267. [CrossRef]

6. $\quad$ Lachapelle, U.; Frank, L.; Saelens, B.; Sallis, J.F.; Conway, T.L. Commuting by Public Transit and Physical Activity: Where You Live, Where You Work, and How You Get There. J. Phys. Act. Health 2011, 8, S72-S82. [CrossRef]

7. Ibrahim, R.; Clayden, A.; Cameron, R. Tropical urban parks in Kuala Lumpur, Malaysia: Challenging the attitudes of park management teams towards a more environmentally sustainable approach. Urban For. Urban Green. 2020, 49, 126605. [CrossRef]

8. Noor, N.M.; Rosni, N.A.; Hashim, M.; Abdullah, A. Developing land use geospatial indices (LUGI) for sprawl measurement in alpha cities: Case study of Kuala Lumpur, Malaysia. Cities 2018, 82, 127-140. [CrossRef]

9. Maruthaveeran, S.; Bosh, C.K.V.D. Fear of crime in urban parks-What the residents of Kuala Lumpur have to say? Urban For. Urban Green. 2015, 14, 702-713. [CrossRef]

10. Chuen, O.C.; Karim, M.R.; Yusoff, S. Mode Choice between Private and Public Transport in Klang Valley, Malaysia. Sci. World J. 2014, 2014, 1-14. [CrossRef]

11. Mohamad, J.; Kiggundu, A.T. The Rise of the Private Car in Kuala Lumpur, Malaysia. IATSS Res. 2007, 31, 69-77. [CrossRef] 
12. Borhan, M.N.; Ibrahim, A.N.H.; Miskeen, M.A.A. Extending the theory of planned behaviour to predict the intention to take the new high-speed rail for intercity travel in Libya: Assessment of the influence of novelty seeking, trust and external influence. Transp. Res. Part A Policy Pract. 2019, 130, 373-384. [CrossRef]

13. Ibrahim, A.N.H.; Borhan, M.N.; Md Yusoff, N.I.; Ismail, A. Rail-based Public Transport Service Quality and User Satisfaction-A Literature Review. Promet-Traffic Transp. 2020, 32, 423-435. [CrossRef]

14. Ibrahim, A.N.H.; Borhan, M.N. Sex Disparity in Satisfaction and Loyalty towards Urban Rail Transit: A Survey of Light Rail Transit (LRT) Passengers in Kuala Lumpur, Malaysia. Int. J. Integr. Eng. 2021, 13, 223-228. [CrossRef]

15. Masirin, M.I.M.; Salin, A.M.; Zainorabidin, A.; Martin, D.; Samsuddin, N. Review on Malaysian Rail Transit Operation and Management System: Issues and Solution in Integration. IOP Conf. Series Mater. Sci. Eng. 2017, 226, 012029. [CrossRef]

16. Zulkifli, S.N.A.M.; Hamsa, A.A.K.; Noor, N.M.; Ibrahim, M. Evaluation of land use density, diversity and ridership of Rail Based Public Transportation System. Transp. Res. Procedia 2017, 25, 5266-5281. [CrossRef]

17. Ibrahim, A.N.H.; Borhan, M.N.; Zakaria, N.A.; Zainal, S.K. Effectiveness of Commuter Rail Service toward Passenger's Satisfaction: A Case Study from Kuala Lumpur, Malaysia. Int. J. Eng. Technol. 2019, 8, 50-55. [CrossRef]

18. Van Lierop, D.; Badami, M.G.; El-Geneidy, A.M. What influences satisfaction and loyalty in public transport? A review of the literature. Transp. Rev. 2018, 38, 52-72. [CrossRef]

19. Spickermann, A.; Grienitz, V.; Von Der Gracht, H.A.; Abbas, R.; Michael, K.; Michael, M.; Redman, L.; Friman, M.; Gärling, T.; Hartig, T. Quality attributes of public transport that attract car users: A research review. Transp. Policy 2013, 25, 119-127. [CrossRef]

20. Belwal, R. Public transportation in Oman: A strategic analysis. Adv. Transp. Stud. 2017, 42, 99-116. [CrossRef]

21. Chowdhury, S.; Ceder, A. (Avi) Users' willingness to ride an integrated public-transport service: A literature review. Transp. Policy 2016, 48, 183-195. [CrossRef]

22. Shen, W.; Xiao, W.; Wang, X. Passenger satisfaction evaluation model for Urban rail transit: A structural equation modeling based on partial least squares. Transp. Policy 2016, 46, 20-31. [CrossRef]

23. Lai, W.-T.; Chen, C.-F. Behavioral intentions of public transit passengers-The roles of service quality, perceived value, satisfaction and involvement. Transp. Policy 2011, 18, 318-325. [CrossRef]

24. Yilmaz, V.; Ari, E. The effects of service quality, image, and customer satisfaction on customer complaints and loyalty in high-speed rail service in Turkey: A proposal of the structural equation model. Transp. A Transp. Sci. 2016, 13, 67-90. [CrossRef]

25. De Oña, J.; de Oña, R.; Eboli, L.; Mazzulla, G. Perceived service quality in bus transit service: A structural equation approach. Transp. Policy 2013, 29, 219-226. [CrossRef]

26. Lei, P.-W.; Wu, Q. Introduction to Structural Equation Modeling: Issues and Practical Considerations. Educ. Meas. Issues Pract. 2007, 26, 33-43. [CrossRef]

27. Williams, L.J.; Vandenberg, R.J.; Edwards, J.R. 12 Structural Equation Modeling in Management Research: A Guide for Improved Analysis. Acad. Manag. Ann. 2009, 3, 543-604. [CrossRef]

28. Astrachan, C.B.; Patel, V.K.; Wanzenried, G. A comparative study of CB-SEM and PLS-SEM for theory development in family firm research. J. Fam. Bus. Strat. 2014, 5, 116-128. [CrossRef]

29. Fornell, C.; Johnson, M.D.; Anderson, E.W.; Bryant, B.E. The American Customer Satisfaction Index: Nature, Purpose, and Findings. J. Mark. 1996, 60, 7-18. [CrossRef]

30. Johnson, M.D.; Gustafsson, A.; Andreassen, T.W.; Lervik, L.; Cha, J. The evolution and future of national customer satisfaction index models. J. Econ. Psychol. 2001, 22, 217-245. [CrossRef]

31. Oliver, R.L. A Cognitive Model of the Antecedents and Consequences of Satisfaction Decisions. J. Mark. Res. 1980, 17, 460-469. [CrossRef]

32. Oliver, R.L. Satisfaction: A Behavioral Perspective on the Consumer, 2nd ed.; McGraw Hill: New York, NY, USA, 2010.

33. Zhang, C.; Liu, Y.; Lu, W.; Xiao, G. Evaluating passenger satisfaction index based on PLS-SEM model: Evidence from Chinese public transport service. Transp. Res. Part A Policy Pr. 2019, 120, 149-164. [CrossRef]

34. Hussain, R.; Al Nasser, A.; Hussain, Y.K. Service quality and customer satisfaction of a UAE-based airline: An empirical investigation. J. Air Transp. Manag. 2015, 42, 167-175. [CrossRef]

35. Fu, X.-M.; Zhang, J.-H.; Chan, F.T. Determinants of loyalty to public transit: A model integrating Satisfaction-Loyalty Theory and Expectation-Confirmation Theory. Transp. Res. Part A Policy Pr. 2018, 113, 476-490. [CrossRef]

36. Lien, C.-H.; Wu, J.-J.; Chen, Y.-H.; Wang, C.-J. Trust transfer and the effect of service quality on trust in the healthcare industry. Manag. Serv. Qual. Int. J. 2014, 24, 399-416. [CrossRef]

37. Parasuraman, A.; Zeithaml, V.A.; Berry, L.L. A Conceptual Model of Service Quality and Its Implications for Future Research. J. Mark. 1985, 49, 41. [CrossRef]

38. Jiang, H.; Zhang, Y. An investigation of service quality, customer satisfaction and loyalty in China's airline market. J. Air Transp. Manag. 2016, 57, 80-88. [CrossRef]

39. Hu, H.-H.; Kandampully, J.; Juwaheer, T.D. Relationships and impacts of service quality, perceived value, customer satisfaction, and image: An empirical study. Serv. Ind. J. 2009, 29, 111-125. [CrossRef]

40. Mouwen, A. Drivers of customer satisfaction with public transport services. Transp. Res. Part A Policy Pr. 2015, 78, 1-20. [CrossRef]

41. Marakanon, L.; Panjakajornsak, V. Perceived quality, perceived risk and customer trust affecting customer loyalty of environmentally friendly electronics products. Kasetsart J. Soc. Sci. 2017, 38, 24-30. [CrossRef] 
42. Yanık, S.; Aktas, E.; Topcu, I. Traveler satisfaction in rapid rail systems: The case of Istanbul metro. Int. J. Sustain. Transp. 2017, 11, 642-658. [CrossRef]

43. Weinstein, A. Customer Satisfaction Among Transit Riders: How Customers Rank the Relative Importance of Various Service Attributes. Transp. Res. Rec. J. Transp. Res. Board 2000, 1735, 123-132. [CrossRef]

44. Tyrinopoulos, Y.; Antoniou, C. Public transit user satisfaction: Variability and policy implications. Transp. Policy 2008, 15, 260-272. [CrossRef]

45. Das, A.M.; Ladin, M.A.; Ismail, A.; Rahmat, R.O.K. Consumers satisfaction of public transport monorail user in Kuala Lumpur. J. Eng. Sci. Technol. 2013, 8, 272-283.

46. De Oña, J.; de Oña, R.; Eboli, L.; Mazzulla, G. Heterogeneity in Perceptions of Service Quality among Groups of Railway Passengers. Int. J. Sustain. Transp. 2014, 9, 612-626. [CrossRef]

47. Eboli, L.; Fu, Y.; Mazzulla, G. Multilevel Comprehensive Evaluation of the Railway Service Quality. Procedia Eng. 2016, 137, 21-30. [CrossRef]

48. Paramita, P.; Zheng, Z.; Haque, M.; Washington, S.; Hyland, P. User satisfaction with train fares: A comparative analysis in five Australian cities. PLoS ONE 2018, 13, e0199449. [CrossRef]

49. Oliver, R.L.; Desarbo, W.S. Response Determinants in Satisfaction Judgments. J. Consum. Res. 1988, 14, 495-507. [CrossRef]

50. Bolton, R.; Drew, J.H. A Longitudinal Analysis of the Impact of Service Changes on Customer Attitudes. J. Mark. 1991, 55, 1. [CrossRef]

51. Zeithaml, V.A. Consumer Perceptions of Price, Quality, and Value: A Means-End Model and Synthesis of Evidence. J. Mark. 1988, 52, 2-22. [CrossRef]

52. Yang, Z.; Peterson, R.T. Customer perceived value, satisfaction, and loyalty: The role of switching costs. Psychol. Mark. 2004, 21, 799-822. [CrossRef]

53. Irtema, H.I.M.; Ismail, A.; Borhan, M.N.; Das, A.M.; Alshetwi, A.B. Case study of the behavioural intentions of public transportation passengers in Kuala Lumpur. Case Stud. Transp. Policy 2018, 6, 462-474. [CrossRef]

54. Sumaedi, S.; Mahatma, I.G.; Bakti, Y.; Yarmen, M. The empirical study of public transport passengers' behavioral intentions: The roles of service quality, perceived sacrifice, perceived value, and satisfaction (case study: Paratransit passengers in Ja-karta, Indonesia). Int. J. Traffic Transp. Eng. 2012, 2, 83-97.

55. Widianti, T.; Sumaedi, S.; Bakti, I.G.M.Y.; Rakhmawati, T.; Astrini, N.J.; Yarmen, M. Factors influencing the behavioral intention of public transport passengers. Int. J. Qual. Reliab. Manag. 2015, 32, 666-692. [CrossRef]

56. Kim, S.A. Study on the Service Model of the Public Libraries for Dyslexics. J. Korean Libr. Inf. Sci. Soc. 2009, 40, 183-206. [CrossRef]

57. Pratiwi, P.U.D.; Landra, N.; Kusuma, G.A.T. The Construction of Public Transport Service Model to Influence the Loyalty of Customer. Sci. Res. J. 2018, VI, 56-63.

58. Cheng, Y.-H.; Tseng, W.-C. Exploring the effects of perceived values, free bus transfer, and penalties on intermodal metro-bus transfer users' intention. Transp. Policy 2016, 47, 127-138. [CrossRef]

59. Ibrahim, A.; Borhan, M.; Yusoff, N.M.; Ismail, A.; Yazid, M.M.; Yunin, N.M.; Sotaro, Y. Gender and Age Do Matter: Exploring the Effect of Passengers' Gender and Age on the Perception of Light Rail Transit Service Quality in Kuala Lumpur, Malaysia. Sustainability 2021, 13, 990. [CrossRef]

60. Borhan, M.N.; Ibrahim, A.N.H.; Aziz, A.; Yazid, M.R.M. The relationship between the demographic, personal, and social factors of Malaysian motorcyclists and risk taking behavior at signalized intersections. Accid. Anal. Prev. 2018, 121, 94-100. [CrossRef]

61. Hair, J.F.; Black, W.C.; Babin, B.J.; Anderson, R.E. Multivariate Data Analysis; Prentice Hall: Ithaca, NY, USA, 2010; ISBN 9781292021904.

62. Fornell, C.; Larcker, D.F. Evaluating Structural Equation Models with Unobservable Variables and Measurement Error. J. Mark. Res. 1981, 18, 39-50. [CrossRef]

63. Kwan, S.C.; Tainio, M.; Woodcock, J.; Sutan, R.; Hashim, J.H. The carbon savings and health co-benefits from the introduction of mass rapid transit system in Greater Kuala Lumpur, Malaysia. J. Transp. Health 2017, 6, 187-200. [CrossRef]

64. Phoong, S.Y.; Moghavvemi, S.; Phoong, K.H. User Perception on Urban Light Rail Transit. Civ. Eng. Arch. 2019, 7, 43-49. [CrossRef]

65. Joewono, T.B.; Kubota, H. Paratransit Service in Indonesia: User Satisfaction and Future Choice. Transp. Plan. Technol. 2008, 31, 325-345. [CrossRef]

66. Jain, S.; Aggarwal, P.; Kumar, P.; Singhal, S.; Sharma, P. Identifying public preferences using multi-criteria decision making for assessing the shift of urban commuters from private to public transport: A case study of Delhi. Transp. Res. Part F Traffic Psychol. Behav. 2014, 24, 60-70. [CrossRef]

67. Chandra, S.; Bari, M.E.; Devarasetty, P.C.; Vadali, S. Accessibility evaluations of feeder transit services. Transp. Res. Part A Policy Pr. 2013, 52, 47-63. [CrossRef] 